Sección Sur-Sur

\title{
Enhancing Sustainable Performance through Green Supply Chain Management Practices: A Study of Malaysian Manufacturing Firms
}

Mejora del rendimiento sostenible a través de las prácticas de gestión de la cadena de suministro verde: un estudio de empresas manufactureras de Malasia

\author{
Rohani Abdullah | Universiti Utara Malaysia - MALAYSIA | \\ Corresponding author. School of Technology Management and Logistics, Universiti Utara Malaysia; rhani@uum.edu.my \\ Marini Nurbanum Mohamad | Universiti Utara Malaysia - MALAYSIA | \\ School of Management, Universiti Sains Malaysia. E-mail: marini_nur@usm.my \\ Ramayah Thurasamy | Universiti Utara Malaysia - MALAYSIA | \\ School of Management, Universiti Sains Malaysia. E-mail: ramayah@usm.my
}

\begin{abstract}
This paper investigates the effects of green supply chain management practices on sustainable performance. This study sent a survey to 616 Malaysian ISO 14001 certified manufacturing companies. With a total of 152 usable questionnaires, the response rate was $24.68 \%$. The findings showed that green purchasing and eco-design were found to improve all the components of sustainable performance. While reverse logistics was found to have a positive impact on social performance only. These relationships indicate that Green Supply Chain Management Practices can be of value to organizations specifically, as well to the external environment at large.
\end{abstract}

Keywords: Eco-design, Green Purchasing, Reverse Logistics, Sustainable Performance, Manufacturing companies

RESUMEN: Este artículo investiga los efectos de las prácticas de gestión de la cadena de suministro verde en el desempeño sostenible. Se necesitan más estudios en el área debido al inmenso impacto que puede traer al desempeño económico, ambiental y social de las empresas. Este estudio envío una encuesta a 616 empresas de fabricación con certificación ISO 14001 de Malasia, con un total de 152 cuestionarios utilizables, la tasa de respuesta fue del 24,68\%. Los resultados mostraron que las compras ecológicas y el diseño ecológico mejoraron todos los componentes del rendimiento sostenible. Si bien se encontró que la logística inversa solo tiene un impacto positivo en el desempeño social. Estas relaciones indican que las prácticas de gestión de la cadena de suministro verde pueden ser valiosas para las organizaciones en particular, así como para el entorno externo en general.

Palabras clave: ecodiseño, compras verdes, logística inversa, rendimiento sostenible, empresas de fabricación. 


\section{INTRODUCTION}

The manufacturing sector is considered one of the major contributors after the services sector in Malaysia's economy. However, the rising of the manufacturing sector has a negative impact upon the environment by causing increase in pollution, waste and the depletion of natural resources. In other words, the main source of environmental problems lies in industry as people nowadays significantly relies on industrial products to maintain their living standards. As a consequence, this results in the detrimental impact on the environment and the future of human society. For this reason, the Malaysian government focuses on environmental aspects in its Tenth Malaysia Plan (10MP, 2011-2015) called "Building an environment that enhances quality of life". The 10th Malaysia Plan details measures to be taken to achieve this goal. The desired quality of life can only be achieved within a stable and well-preserved environment. According to the plan, the Malaysian government will introduce new legislation and incentives to ensure that all industries and consumers comply with the measures necessary to take on the country's environmental problems. This plan has enhanced awareness and understanding on green practices that are in place and are crucial for a sustainable future.

With the aforementioned issues, this study aims to investigate the outcomes of green supply chain practices in terms of sustainable performance. The sustainability concept has increasingly become important in business operations and supply chain management. Research shows that price is no longer the only guide for competition but ecological, health and welfare benefits are involved collectively (Penker, 2006; Suansawat, 2013). In addition, the ongoing pressure from increased globalization and increased competition, the higher demands for safety and security, environmental protection, lack of scarce resources, social and ethical issues have induced immense pressure on supply chain managers (Cetinkaya et al., 2011). As a result, manufacturing firms have not only needed to deliver quality products right on time, but they now also have to comply with environmental, economic, ethical and the social pressures placed on the business. An effective assessment of a sustainable performance passes through the simultaneous evaluation of economic, environmental and social performance. Therefore, the adoption and implementation of green practices should seek to address all the pillars of sustainable performance (Markley \& Davis, 2007; Pietro, 2012).

However, the previous studies on sustainable performance has studied this performance from the point of isolation rather to evaluate the collective view of sustainable performance which embraces the economic, environmental and social performance (Andrea, 2013; Bai, Sarkis, Wei, \& Koh, 2012; El Saadany, Jaber, \& Bonney, 2011; Mohamed \& John, 2002; Pradeepa, Lee, \& Nelson, 2012). This provides greater clarity and support for this study to investigate how implementing green supply chain management practices can contribute to sustainable performance. Overall, the main problem of the study can be stated as follows: "What is the impact of Green Supply Chain Management practices of eco-design, green purchasing and reverse logistics on sustainable performance?".

\section{LITERATURE REVIEW}

Nowadays, "green" has become a buzzword and a common practice to portray the environmentally friendly image of products, processes, systems and technologies and the way business is conducted (Vachon \& Klassen, 2006). However, most of the green practices in place, particularly in developing countries remain at a conventional way of command-and-control solutions where firms try to eliminate or reduce negative environmental impacts after they have been created, rather than seriously be proactive in greening the way on how to conduct business from the beginning of the product cycle in order to reduce the source of waste and pollution (Eltayeb et al., 2011). The conventional approach of green practices is related to numerous weaknesses and problems. This approach does not really eliminate pollutants or reduce negative environmental impact, but simply transforms them from one medium to another (Sarkis, 2006). The setbacks of this approach may expose the firm to negative environmental performance of other firms in its supply chain, this is because the poor environmental performance of supplier is likely to affect the performance and reputation of buying firms (Eltayeb et al., 2011).

Consequently, Green Supply Chain Management (GSCM) is gaining popularity as a management tool in facilitating the green concerns and mitigates the environmental problem. In relation to green supply chain practices in the context of Malaysia, the Malaysian government is promoting the ISO 14001 international environmental management standard through the Standard and Industrial Research Institute of Malaysia (SIRIM), and disseminating environmental information through the Environmental Management and Research Association of Malaysia (ENSEARCH). Among several environmental drivers that SIRIM and ENSEARCH focus on, specific importance has been placed on three fundamental green practices: green purchasing, design for the environment (eco-design) and reverse logistics (Chin-Chun et al., 2013). 


\subsection{Relationship between GSCM practices and Economic Performance}

Economic performance has traditionally, and continues to be, the first priority for manufacturers (Zhu \& Sarkis, 2007), especially manufacturers in developing countries such as Malaysia. Yet environmental performance has become increasingly important. Many manufacturers have started considering and implementing organizational approaches such as cleaner production and environmental management system along with GSCM to improve both environmental and economic performance (Zhu \& Sarkis, 2007). However, whether GSCM practices can improve economic performance is still an open question (Seuring \& Müller, 2008). Some have shown that GSCM have a positive relationship with a firm's economic performance (Tritos et al., 2013). Others have suggested that economic performance is not being reaped in short-term profitability and sales performance when GSCM practices are implemented.

According to Tritos et al. (2013), GSCM practices focus on the elimination of wastes associated with economic sustainability; and such waste minimization should lead to reduced costs resulting in improved economic performance. Meanwhile, Rao and Holt (2005) demonstrated a link between GSCM practices and economic performance. They also found that GSCM practices led to competitiveness and better economic performance. For example, according to Koh, Gunasekaran, and Tseng (2012), eco-design implies effective use of materials and waste reduction. Reduction of waste can lead to better costs for the organization and better use of materials can positively impact economic performance. Empirical studies also found significant positive relationship between GSCM practices and economic performance. Accordingly, the following hypotheses postulate that GSCM practices enhance economic performance:

$\mathrm{H} 1$ : There is a positive relationship between green purchasing and economic performance.

$\mathrm{H} 2$ : There is a positive relationship between eco-design and economic performance.

H3: There is a positive relationship between reverse logistic and economic performance.

\subsection{Relationship between GSCM practices and Environmental Performance}

GSCM practices are developed specifically to improve the environmental performance of manufacturing firms. Practices, such as green purchasing, eco-design and reverse logistics are designed to positively impact environmental performance. The implementation of GSCM practices is expected to result in improved environmental performance as measured by reductions in air emissions, effluent waste, solid waste, and the consumption of toxic materials (Kenneth et al., 2012). Zhu and Sarkis (2004) found a positive relationship between adoption of green supply chain practices and improvements in environmental performance. Whereas, Ramakrishnan et al. (2015) found that green purchasing is likely to result in improved environmental performance. Meanwhile, Diabat and Govindan (2011) studied various drivers that affect the implementation of green supply chains and found that eco-design positively influences the performance of green supply chains. Kenneth et al. (2012) indicated that eco-design and reverse logistic will directly and positively influence environmental performance, whereby the motivation of the manufacturer in this type of green practice will be on reducing the environmental impact of the design. Therefore, the following set of hypotheses postulate that GSCM practices significantly correlated with environmental performance of a firm. It is, therefore proposed that:

H4: There is a positive relationship between green purchasing and environmental performance.

H5: There is a positive relationship between eco-design and environmental performance.

H6: There is a positive relationship between reverse logistic and environmental performance.

\subsection{Relationship between GSCM practices and Social Performance}

The adoption of green practice that generates less pollution is believed to improve the working condition for employees and the community quality of life. Therefore, the implementation of production processes that is environmentally oriented which pollute less can have a positive impact on two aspects of social dimension that focus on employees and community as defined by Elkington (2004). This is further emphasized by Pietro (2012) that firms can achieve several social targets such as customer protection, transparency in the market and environmental preservation. Firms incorporating GSCM into their business actions may thus positively contribute to social performance. 
Although there are limited empirical test of the relationship between green supply chain management practices and social performance found in the literature, the available empirical evidence shows that environmental practices in general, have significant social performance such as customer loyalty (Pietro, 2012) and to enhance organizational image (Eltayeb \& Zailani, 2009). Therefore, this study hypothesizes that:

H7: There is a positive relationship between green purchasing and social performance.

H8: There is a positive relationship between eco-design and social performance.

H9: There is a positive relationship between reverse logistic and social performance.

\section{RESEARCH METHODOLOGY}

The data collection through mail survey. The unit of analysis in this study is an "individual firm". The selection criterion for the targeted unit of analysis is for the firm to be certified in Environmental Management System (EMS) ISO 14001. Firms with an ISO 14001 were chosen since they are expected to have adopted and implemented green supply chain practices. This contention is supported by the studies of Fadhilah (2015), Eltayeb et al. (2011), Tritos et al. (2013), and Zhu et al. (2008).

The listings from SIRIM and Federation Manufacturers Malaysia (FMM) provide the sampling frame for the target population. After conjoining the names of 462 firms from FMM and an additional 413 firms from SIRIM, a total of 875 manufacturing firms with ISO 14001 registrations were obtained. The redundancies were then removed to avoid duplicates of information, resulting in 616 firms in the final list and used for the final survey.

After sending 616 survey forms to the firms in the final list, we received 176 voluntary responses. However, 24 respondent firms had missing answers on more than $50 \%$ of the survey items. After excluding those invalid response forms, the remaining 152 valid responses were retained, which represented a valid response rate of $24.68 \%$.

This study employs a 5-point Likert scale for the entire dimensions of green supply chain management practices. The range of the scale is from $1=$ "very low extent" to $5=$ "very high extent". The green purchasing measurement was adopted from and developed on the basis of the nine basic elements of green purchasing as suggested by Chin-Chun et al. (2013), Zhu et al. (2013), Tritos et al. (2013), and Eltayeb et al. (2010). Table 1 illustrates the adopted measures.

Table 1: Items for Green Purchasing

\begin{tabular}{l} 
1. Provides design specifications to suppliers that include environmental requirements \\
for purchased items. \\
\hline $\begin{array}{l}\text { 2. Requires your suppliers to develop and maintain an environmental management } \\
\text { system (EMS). }\end{array}$ \\
\hline 3. Requires your suppliers to have a certified EMS such as ISO 14001. \\
\hline $\begin{array}{l}\text { 4. Uses a questionnaire to collect information about your suppliers' environmental as- } \\
\text { pects, activities and/or management systems. }\end{array}$ \\
\hline $\begin{array}{l}\text { 5. Makes sure that your purchased products must contain green attributes such as } \\
\text { recycled or reusable items. }\end{array}$ \\
6. Makes sure that your purchased products must not contain environmentally undesir- \\
able items such as lead or other hazardous or toxic materials. \\
\hline 7. Evaluates your suppliers based on specific environmental criteria. \\
\hline 8. Evaluates the environmental aspects of your suppliers. \\
9. Make sure that your suppliers meet its environmental objectives.
\end{tabular}


Accordingly, the measurement items for eco-design were adopted from Eltayeb and Zailani (2009) Tritos et al. (2013), Zhu et al. (2013) and Chin-Chun et al. (2013) as shown in Table 2.

Table 2: Items for Eco-design

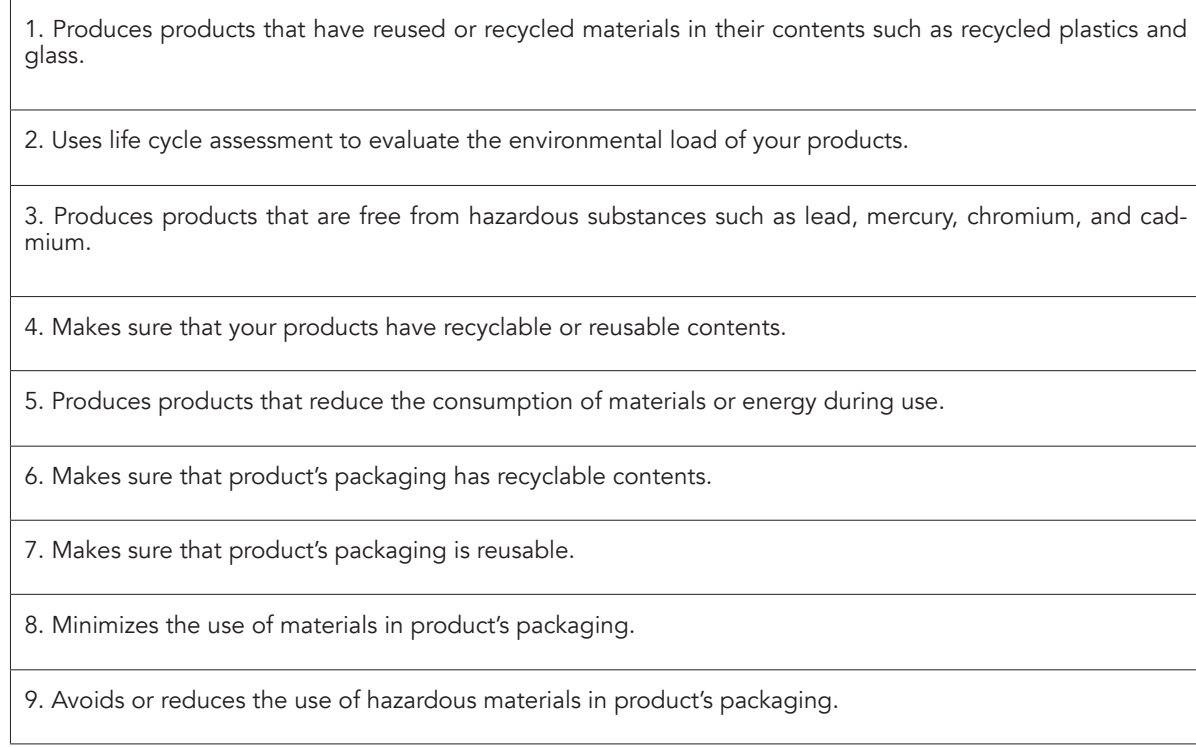

Table 3 illustrates the six items that reflect these elements which were adopted from Eltayeb and Zailani (2009), Tritos et al. (2013) and Chin-Chun et al. (2013).

Table 3: Items for Reverse Logistics

\begin{tabular}{l} 
1. Collects back used products from customers for recycling, reclamation of materials, or \\
reuse. \\
\hline 2. Collects back used packaging from customers reuse or recycling. \\
\hline 3. Requires suppliers to collect back their packaging materials. \\
\hline 4. Returns back its products to suppliers for retaining of materials, or remanufacturing. \\
\hline 5. Returns back its packaging to suppliers for reuse and recycling. \\
\hline 6. Returns back the products from customers for safe refill.
\end{tabular}

For sustainable performance, the performance is defined as the actual impacts of green supply chain practices adoption on environmental, economic and social performance of the firm. Measurement items for the performance were developed from previous studies (Eltayeb and Zailani, 2009; Tritos et al., 2013; Elkington, 2004). For these three types of performance, this study adopts five-point Likert scale that ranges from ' $1=$ Not at all" to " $5=$ Highly significant", with statements signifying the performance actually realized by a firm during the last three years. The list of the measurement used for sustainable performance is shown in Table 4.

Table 4: Items for Sustainable Performance

\begin{tabular}{|l|}
\hline \multicolumn{1}{|c|}{ Economic Performance } \\
\hline 1. Decrease of cost for materials purchasing. \\
\hline 2. Decrease of cost for energy consumption. \\
\hline 3. Decrease of fee for waste treatment. \\
\hline 4. Decrease of fee waste discharge. \\
\hline 5. Decrease of fine/ penalties for environmental accidents. \\
\hline
\end{tabular}




\begin{tabular}{|l|}
\hline \multicolumn{1}{|c|}{ Environmental Performance } \\
\hline 1. Reduction of air emission. \\
\hline 2. Reduction of waste water. \\
\hline 3. Reduction of solid wastes. \\
\hline 4. Decrease of consumption for hazardous/ harmful/ toxic materials. \\
\hline 5. Decrease of frequency for environmental accidents. \\
\hline 6. Improvement of a firm's environmental situation. \\
\hline Social Performance \\
\hline 1. Employees' health and safety \\
\hline 2. Incentives and engagement for local employment. \\
\hline 3. Development of economic activities. \\
\hline 4. Improvement of community health and safety. \\
\hline 5. Reduction of the negative impact of products and processes on the local community. \\
\hline
\end{tabular}

\section{RESULTS AND DISCUSSION}

In order to examine the direct relationship of GSCM practices and Sustainable Performance, path coefficients were checked to assess the significance of the relationship between independent variables and dependent variables. Table 5 summarizes the result of hypothesis testing on the direct effect.

Table 5: Hypotheses Testing: Direct Effects of Green Supply Chain Management Practices on Sustainable Performance

\begin{tabular}{|c|c|c|c|c|c|}
\hline No. & $\begin{array}{l}\text { Path Coefficient } \\
(\beta)\end{array}$ & Standard Error & t-values & $p$-values & Results \\
\hline $\mathrm{H} 1$ & 0.135 & 0.092 & 1.475 & 0.070 & Supported \\
\hline $\mathrm{H} 2$ & 0.129 & 0.097 & 1.329 & 0.092 & Supported \\
\hline $\mathrm{H} 3$ & 0.066 & 0.093 & 0.710 & 0.239 & Not Supported \\
\hline $\mathrm{H} 4$ & 0.223 & 0.095 & 2.355 & 0.009 & Supported \\
\hline $\mathrm{H} 5$ & 0.291 & 0.089 & 3.280 & 0.001 & Supported \\
\hline $\mathrm{H} 6$ & 0.058 & 0.088 & 0.658 & 0.256 & Not Supported \\
\hline $\mathrm{H} 7$ & 0.273 & 0.062 & 4.403 & 0.000 & Supported \\
\hline $\mathrm{H} 8$ & 0.248 & 0.089 & 2.783 & 0.003 & Supported \\
\hline $\mathrm{H} 9$ & 0.238 & 0.075 & 3.178 & 0.001 & Supported \\
\hline
\end{tabular}

Based on the results, all the three GSCM practices of green purchasing, eco-design and reverse logistics are found to have significant positive relationship with social performance $(\boldsymbol{\beta}=0.273, p<0.01 ; \boldsymbol{\beta}=0.248, p<0.01$; $\beta=0.238, p<0.01$ ). Thus, indicating $\mathrm{H} 7, \mathrm{H} 8$ and $\mathrm{H} 9$ are supported. The results suggest that green purchasing, eco-design and reverse logistics that are implemented by the respective firms contributed to the social development because of the firms' sensitivity of accountability for the social welfare of the employees and society.

For the hypotheses that predict the positive relationship of GSCM practices and economic performance, the results of analysis found that green purchasing and eco-design are associated with positive economic performance ( $\beta$ $=0.135, p<0.1 ; \beta=0.129, p<0.1)$. On the other hand, the result revealed that reverse logistics has no relationship with economic performance. Accordingly, hypotheses regarding positive relationship between GSCM practices and economic performance; $\mathrm{H} 1$ and $\mathrm{H} 2$ are supported and $\mathrm{H} 3$ is not supported. The rational for reverse logistics exhibiting non-significant relationship to economic performance, could be due to reverse logistics practices taking a longer period before it shows significant effect on economic performance. Studies reported that in some cases environmental technologies and process changes could have longer payback period (Ghosal, Stephan, \& Weiss, 2014).

For the hypotheses concerning the positive relationship of GSCM practices with environmental performance, the result found that green purchasing and eco-design have positive relationship with environmental performance 
$(\beta=0.223, p<0.01, \beta=0.291, p<0.01)$. While reverse logistics is found to have no relationship on environmental performance. Thus, hypotheses regarding relationship of GSCM practices and environment performance; $\mathrm{H} 4$ and $\mathrm{H} 5$ are supported, while $\mathrm{H} 6$ is not supported. For reverse logistic practice, the result of no positive relationship towards environmental performance can be explained by the fact that the practice of reverse logistics in Malaysia is not extensively put into practice, therefore the effect to the environmental performance were not encouraging. Khor and Udin (2012) reported that Malaysian manufacturing firms accounted lower level of reverse logistics adoption and most of the green practices in place such as reverse logistics was performed merely to meet minimal level of regulative pressure made by the government.

\section{CONCLUSIONS}

Environmental issues have received increasing level of attention both locally and globally. This attention raises questions on how to integrate environmental concerns in business operations and strategy among manufacturing firms. Manufacturing firms in Malaysia is widely known as the major contributor to environmental deterioration, thus, any environmental efforts made by this industry may improve the environmental condition in Malaysia. This study aimed at moving a step forward in understanding how manufacturing firms can improve their sustainability performance by implementing GSCM practices. To this aim, this study has explored the relationships involving GSCM practices; focusing on green purchasing, eco-design and reverse logistics and sustainable performance.

The contribution of the study is to prove the effects of GSCM practices on firm's sustainable performance. This signifies that GSCM practices can be of value to organizations as well the external environment. Green purchasing, eco-design and reverse logistics can generate benefits to the environment, in the form of reduced waste and better resource utilization, in addition to economic benefits such as cost reduction to the organizations. Therefore, GSCM practices can play a significant role in achieving the sustainable performance of economic, environmental and social performance (Bai et al., 2012) and thus contributing to sustainable development of the country.

\section{ACKNOWLEDGMENT}

The authors would like to express their appreciation to Universiti Sains Malaysia Research University (RU) Grant (1001/PMGT/816262) for the financial support to carry out this research.

\section{BIBLIOGRAPHIC REFERENCES}

Andrea, C. (2013). Designing an environmentally sustainable supply chain through ISO 14001 standard. Management of Environmental Quality: An International Journal, 24(1), 16-33.

Bai, C., Sarkis, J., Wei, X., \& Koh, L. (2012). Evaluating ecological sustainable performance measures for supply chain management. Supply Chain Management: An International Journal, 17(1), 78-92.

Cetinkaya, B., Cuthbertson, R., Ewer, G., Klaas-Wissing, T., Piotrowicz, W., \& Tyssen. (2011). Sustainable Supply Chain Management (pp. 189-190): Springer.

Chin-Chun, H., Keah, C. T., Zailani, S. H. M., \& Vaidyanathan, J. (2013). Supply chain drivers that foster the development of green initiatives in an emerging economy. International Journal of Operations \& Production Management, 33(6), 656-688.

Diabat, A., \& Govindan, K. (2011). An analysis of the drivers affecting the implementation of green supply chain management. Resources, Conservation and Recycling, 55, 659-667.

El Saadany, A. M. A. a., Jaber, M. Y., \& Bonney, M. (2011). Environmental performance measures for supply chains. Management Research Review, 34(11), 1202-1221.

Elkington, J. (2004). The Triple Bottom Line: Does it all Add Up? London: Earthscan.

Eltayeb, T. K., \& Zailani, S. H. M. (2009). Going Green through Green Supply Chain Initiatives towards Environmental Sustainability. Operations \& Supply Chain Management, 2(2), 93-110.

Eltayeb, T. K., Zailani, S. H. M., \& Jayaraman, K. (2010). The examination on the drivers for green purchasing adoption among EMS 14001 certified companies in Malaysia. Journal of Manufacturing Technology Management, 21(2), $206-225$.

Eltayeb, T. K., Zailani, S. H. M., \& Ramayah, T. (2011). Green supply chain initiatives among certified companies in Malaysia and environmental sustainability: Investigating the outcomes. Resource, Conservation and Recycling, 55, 495-506.

Fadhilah, M. Z. (2015). Determinants and Consequences of Green Innovation Adoption: A study on ISO 14001 Manufacturing Firms in Malaysia. Doctor of Philosophy, Universiti Sains Malaysia, Pulau Pinang.

Ghosal, V., Stephan, A., \& Weiss, J. (2014). Decentralized Regulation, Environmental Efficiency and Productivity: Centre of Excellence for Science and Innovation Studies (CESIS).

Kenneth, W. G. J., Pamela, J. Z., Jeramy, M., \& Vikram, S. B. (2012). Green supply chain management practices: impact on performan- 
ce. Supply Chain Management: An International Journal, 17(3), 290-305.

Khor, K. S., \& Udin, Z. M. (2013). Reverse logistics in Malaysia: Investigating the effect of green product design and resource commitment. Resources, Conservation and Recycling, 81, 71-80.

Koh, S. C. L., Gunasekaran, A., \& Tseng, C. S. (2012). Cross-tier ripple and indirect effects of directives WEEE and RoHS on greening a supply chain. International Journal of Production Economics, 140(1), 305-317.

Markley, M. J., \& Davis, L. (2007). Exploring future competitive advantage through supply chain. International Journal of Physical Distribution \& Logistics Management, 37(9), 763-774

Mohamed, Z., \& John, P. (2002). The impact of social responsibility on business performance Managerial Auditing Journal 17(4), $174-$ 178.

Penker, M. (2006). Mapping and measuring the ecological embeddedness of food supply chains. Geoforum, 37(3), 368-379.

Pietro, D. G. (2012). Do internal and external environmental management contribute to the triple bottom line? International Journal of Operations \& Production Management, 32(3), 265-290.

Pradeepa, J., Lee, S., \& Nelson, P. (2012). Role of Supply Chain Mapping in Sustainable Supply Chain Management. Paper presented at the 2nd International Conference on Management, Holiday Villa Beach Resort \& SPA, Langkawi Kedah, Malaysia.

Ramakrishnan, P., Haron, S., \& Yen-Nee, G. (2015). Factors Influencing Green Purchasing Adoption for Small and Medium Enterprises (SMEs) in Malaysia. International Journal of Business and Society, 16(1), 39 - 56.

Rao, P., \& Holt, D. (2005). Do green supply chains lead to competitiveness and economic performance? International Journal of Operations and Production Management, 25(9), 898-916.

Sarkis, J. (2006). (ed.) Greening the Supply Chain. London: Springer.

Seuring, S., \& Müller, M. (2008). Core Issues in Sustainable Supply Chain Management - a Delphi Study. Business Strategy and the Environment, 17, 455-466

Suansawat, R. (2013). The Influence of Supply Chain Integration and Green Supply Chain Management Practices on Sustainable Firm Performance - in Thai Manufacturing Industry. Doctor of Philosophy, The University of Hull.

Tritos, L., Dotun, A., \& Keah, C. T. (2013). Green supply chain management practices and performance. Industrial Management \& Data Systems, 113(8), 1088-1109.

Vachon, S., \& Klassen, R. (2006). Extending green practices across the supply chain. The impact of upstream and downstream integration. International Journal of Operations \& Production Management, 26(7), 795-821.

Zhu, Q., \& Sarkis, J. (2004). Relationships between operational practices and performance among early adopters of green supply chain management practices in Chinese manufacturing enterprises. Journal of Operations Management, 22(3), 265-289.

Zhu, Q., \& Sarkis, J. (2007). The moderating effects of institutional pressures on emergent green supply chain practices and performance. International Journal of Production Research, 45(18-19), 4333-4355.

Zhu, Q., Sarkis, J., \& Lai, K.-h. (2008). Confirmation of a measurement model for green supply chain management practices implementation. Int. J. Production Economics, 111, 261-273.

Zhu, Q., Sarkis, J., \& Lai, K.-h. (2013). Institutional-based antecedents and performance outcomes of internal and external green supply chain management practices. Journal of Purchasing \& Supply Management, 19, 106-117

How to cite this article: Abdullah, R., Nurbanum Mohamad, M., \& Thurasamy, R. (2020). Enhancing Sustainable Performance through Green Supply Chain Management Practices: A Study of Malaysian Manufacturing Firms. Religación. Revista De Ciencias Sociales Y Humanidades, 5(23), 163-170. Retrieved from http://revista.religacion.com/index.php/religacion/article/ view/610

Submitted: 18 November 2020 Accepted: 09 February 2020 Published: 31 March 2020 